\title{
Origin of Unconsolidated Quaternary Deposits at Harriet Point near Redoubt Volcano, Alaska
}

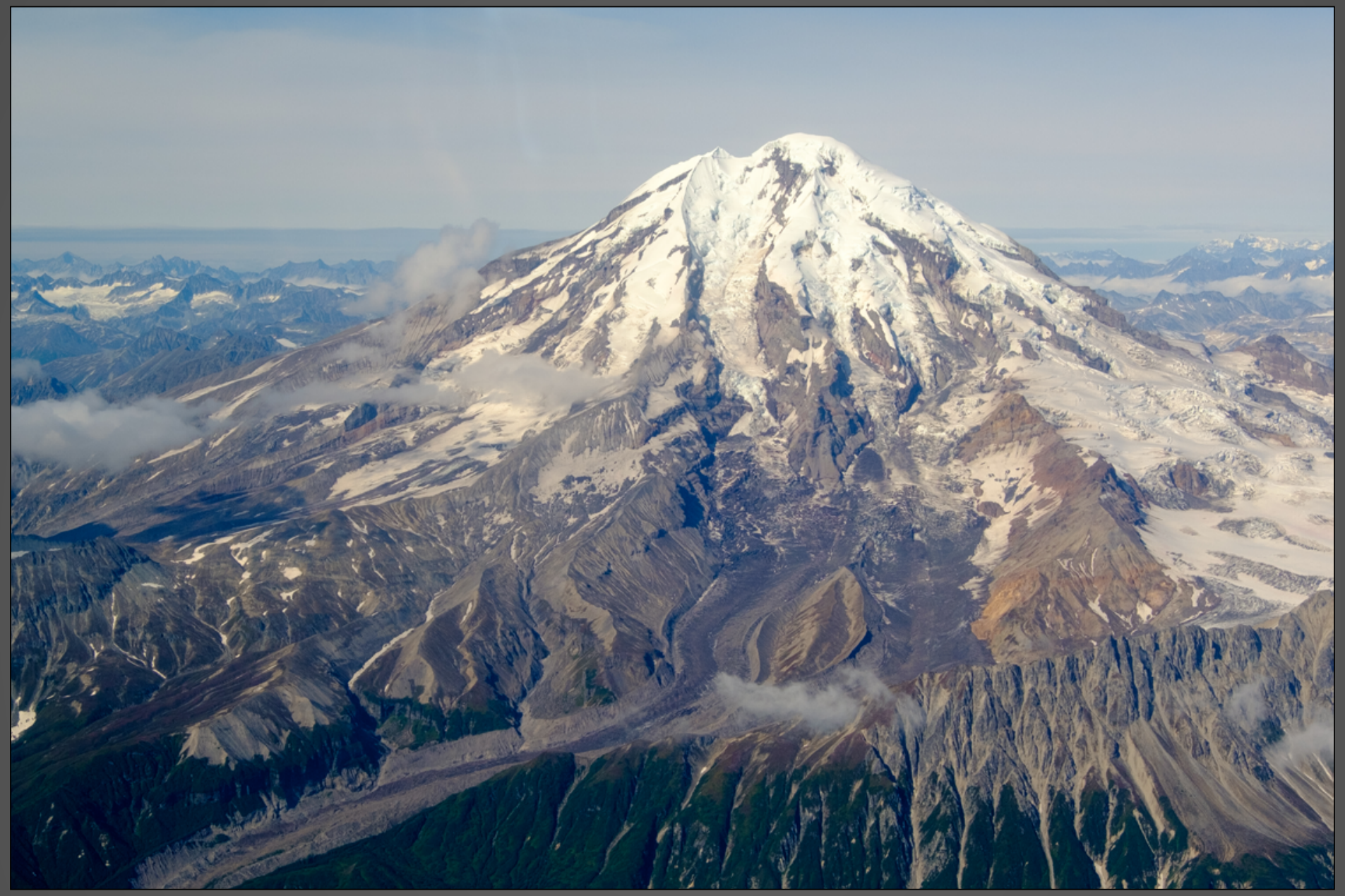

Scientific Investigations Report 2021-5071 
Cover. Aerial photograph showing the east flank of Redoubt Volcano and upper part of the Redoubt Creek drainage. Photograph by M. Loewen, U.S. Geological Survey, September 6, 2018. 


\section{Origin of Unconsolidated Quaternary Deposits at Harriet Point near Redoubt Volcano, Alaska}

By Christopher F. Waythomas

Scientific Investigations Report 2021-5071 


\section{U.S. Geological Survey, Reston, Virginia: 2021}

For more information on the USGS - the Federal source for science about the Earth, its natural and living resources, natural hazards, and the environment-visit https://www.usgs.gov or call 1-888-ASK-USGS (1-888-275-8747).

For an overview of USGS information products, including maps, imagery, and publications, visit https://store.usgs.gov.

Any use of trade, firm, or product names is for descriptive purposes only and does not imply endorsement by the U.S. Government.

Although this information product, for the most part, is in the public domain, it also may contain copyrighted materials as noted in the text. Permission to reproduce copyrighted items must be secured from the copyright owner.

Suggested citation:

Waythomas, C.F., 2021, Origin of unconsolidated Quaternary deposits at Harriet Point near Redoubt Volcano, Alaska: U.S. Geological Survey Scientific Investigations Report 2021-5071, 14 p., https://doi.org/10.3133/sir20215071.

ISSN 2328-0328 (online) 


\section{Contents}

Abstract

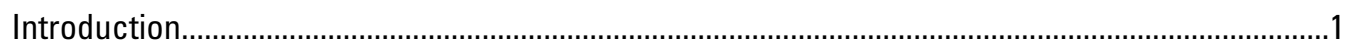

Deposits at Harriet Point

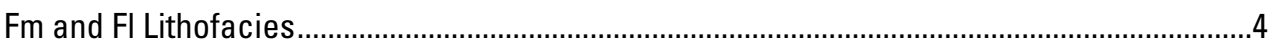

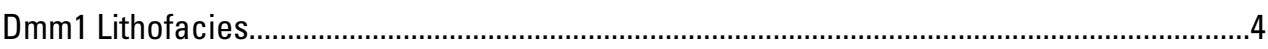

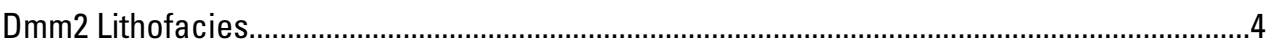

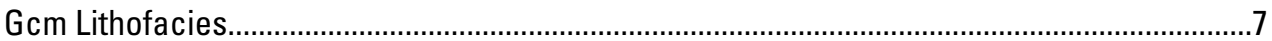

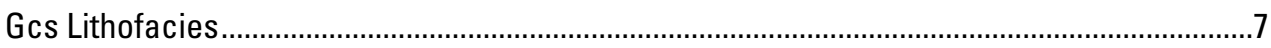

Stratigraphy and Interpretation of Deposits at Harriet Point ............................................................

Depositional Model for Harriet Point Deposits .............................................................................

Reevaluation of Harriet Point Debris-Avalanche Deposit................................................................11

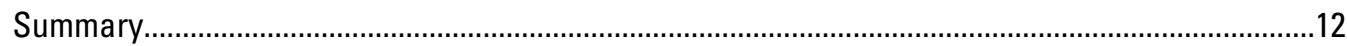

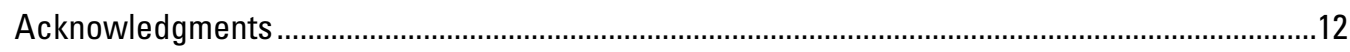

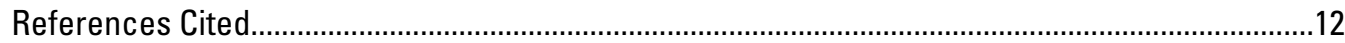

\section{Figures}

1. Maps showing the location of Harriet Point and Redoubt Volcano in the Cook Inlet region of south-central Alaska ..........................................................................................

2. Photograph and sketch showing sea bluff exposure at Harriet Point on the west side of Cook Inlet near Redoubt Volcano .....................................................................................

3. Photograph showing unconsolidated deposits exposed at Harriet Point ..........................4

4. Geologic map of the Redoubt Volcano-Harriet Point-Kalgin Island area of south-central Alaska from Wilson and others (2012) ...........................................................................

5. Photographs showing unconsolidated deposits exposed in the lower part of sea bluffs at Harriet Point...............................................................................................................

6. Photograph showing unconsolidated deposits of lithofacies Dmm1 at Harriet Point ......6

7. Photographs showing unconsolidated deposits exposed in the southern part of Harriet Point bluff..

8. Schematic diagram showing a depositional model for unconsolidated deposits at

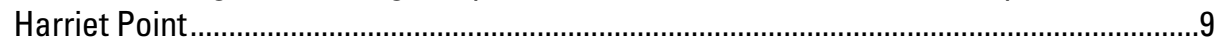

9. Map of glacial deposits and landforms in the Redoubt Creek-Harriet Point area..........10

10. Image showing inundation of the Redoubt Creek drainage by volcanic landslides estimated with the numerical model LAHARZ (Schilling, 1998; Griswold and Iverson, 2008)....11

\section{Table}

1. Explanation of lithofacies code, modified from Eyles and others (1983) .......................... 


\section{Conversion Factors}

International System of Units to U.S. customary units

\begin{tabular}{lcl}
\hline \multicolumn{1}{c}{ Multiply } & \multicolumn{1}{c}{ By } & \multicolumn{1}{c}{ To obtain } \\
\hline meter $(\mathrm{m})$ & Length & \\
kilometer $(\mathrm{km})$ & 3.281 & foot $(\mathrm{ft})$ \\
\multicolumn{3}{c}{ Area } \\
\hline square meter $\left(\mathrm{m}^{2}\right)$ & 0.6214 & mile $(\mathrm{mi})$ \\
square kilometer $\left(\mathrm{km}^{2}\right)$ & 10.76 & square foot $\left(\mathrm{ft}^{2}\right)$ \\
& 0.3861 & square mile $\left(\mathrm{mi}^{2}\right)$ \\
\hline cubic kilometer $\left(\mathrm{km}^{3}\right)$ & Volume & \\
\hline
\end{tabular}

\section{Abbreviations}

cal. yr B.P. calibrated years before present

ky thousand years

$\mathrm{Ma} \quad$ million years before present

yr B.P. years before present 


\title{
Origin of Unconsolidated Quaternary Deposits at Harriet Point near Redoubt Volcano, Alaska
}

\author{
By Christopher F. Waythomas
}

\section{Abstract}

Unconsolidated boulder-rich diamicton units exposed in sea cliffs at Harriet Point southeast of Redoubt Volcano were evaluated to better understand their provenance relative to the late Quaternary eruptive history of the volcano. A previous study concluded that deposits at Harriet Point were emplaced by a large volcanic landslide originating on the southeast flank of Redoubt Volcano (Begét and Nye, 1994). Field-based analysis of the stratigraphy and sedimentology of the Harriet Point deposits and numerical simulations of the volcanic landslide area of inundation indicate that none of the deposits are volcanogenic. All of the unconsolidated boulder-rich diamicton units at Harriet Point are glacial in origin and can be reconciled using the presently available model for late Quaternary glaciation of Cook Inlet.

\section{Introduction}

Unconsolidated deposits on the flanks of volcanoes provide an important record of primary eruptive events and can be useful chronostratigraphic markers when part of nonvolcanic sequences. Such deposits are key to interpreting the eruptive history of a volcano and provide context for assessing volcanic hazards. Ascribing a mode of origin to unconsolidated volcanic deposits can be difficult and fraught with uncertainty because deposits can appear sedimentologically similar despite having vastly different origins.

As part of ongoing studies of Redoubt Volcano by the Alaska Volcano Observatory, we have evaluated the postglacial (upper Pleistocene through Holocene) record of eruptive activity through outcrop-scale studies of unconsolidated deposits preserved on the flanks and in the general vicinity of the volcano. Our focus was on tephra-fall deposits and volcaniclastic mass-flow deposits, including the lahar, pyroclastic-density current, and debrisavalanche deposits common in the main drainages of the volcano. Our goals were to document physical evidence for postglacial eruptive events and integrate the results with existing records of Redoubt Volcano eruptive activity derived from the study by Schiff and others (2010) of tephra deposits in lake cores near the volcano.

After the 1989-90 Redoubt Volcano eruption, various studies were initiated to better understand the effects of the eruption (Miller and Chouet, 1994). An associated study sought to evaluate the eruptive history of Redoubt Volcano on the basis of historical activity and the geologic record of volcaniclastic deposits preserved on the flanks of the volcano (Begét and Nye, 1994). In that study, Begét and Nye (1994) described "a previously unrecognized debris-avalanche deposit from Redoubt Volcano" exposed in sea cliffs southeast of the volcano at Harriet Point (fig. 1). Begét and Nye (1994) estimated an areal extent of about 40 square kilometers $\left(\mathrm{km}^{2}\right)$ for the deposit, which they called the Harriet Point debris-avalanche deposit, and gave an age of emplacement of 13,000 to 10,500 years before present (yr B.P.; uncalibrated). If the deposit had a thickness of 1 to 5 meters (m), a plausible range for debris avalanches (Siebert, 1984), the volume of the volcanic mass flow would have been 0.04 to 0.2 cubic kilometers $\left(\mathrm{km}^{3}\right)$ - a small deposit relative to other terrestrial volcanic debris-avalanche deposits on Earth (Siebert, 1984; Shea and van Wyk de Vries, 2008).

Large volcanic debris-avalanche deposits $\left(>1 \mathrm{~km}^{3}\right)$ are typically associated with a major sector collapse event that leaves behind a tell-tale horseshoe-shaped scar on a truncated edifice (Voight and others, 1983; Capra and others, 2002; Ponomareva and others, 2006). Such scars persist for tens of thousands of years (Siebert, 1984). The modern volume of the Redoubt Volcano edifice is about 30 to $35 \mathrm{~km}^{3}$, and although the configuration of the volcano when the Harriet Point deposit may have been emplaced is not known, there is no evidence the volcano was notably different around 13,000 years ago except that it supported a more extensive cover of glacier ice (Kaufman and others, 2011). Thus, a debris avalanche that originated on the southeast flank of Redoubt Volcano and extended roughly $30 \mathrm{~km}$ to Cook Inlet, forming a $40 \mathrm{~km}^{2}$ deposit — as suggested by Begét and Nye (1994)—would be expected to have left some kind of failure scar, but no such feature has been observed or documented. This report presents field observations and stratigraphic analysis that support a new interpretation of the unconsolidated deposits exposed at Harriet Point as glacial in origin rather than volcanogenic.

\section{Deposits at Harriet Point}

Harriet Point (lat 60²3'43.85” N., long 152¹4'11.26” W.) is a triangular-shaped promontory along the west side of Cook Inlet about 21 kilometers $(\mathrm{km})$ south of the mouth of Drift River, $26 \mathrm{~km}$ northeast of the mouth of Crescent River, and $10 \mathrm{~km}$ west of Kalgin Island, a prominent island in the middle part of Cook Inlet (fig. 1). Unconsolidated surficial deposits are exposed discontinuously for about $6 \mathrm{~km}$ along the promontory in sea cliffs that are as tall as $25 \mathrm{~m}$ (fig. 2). Deposits exposed in the bluff at 


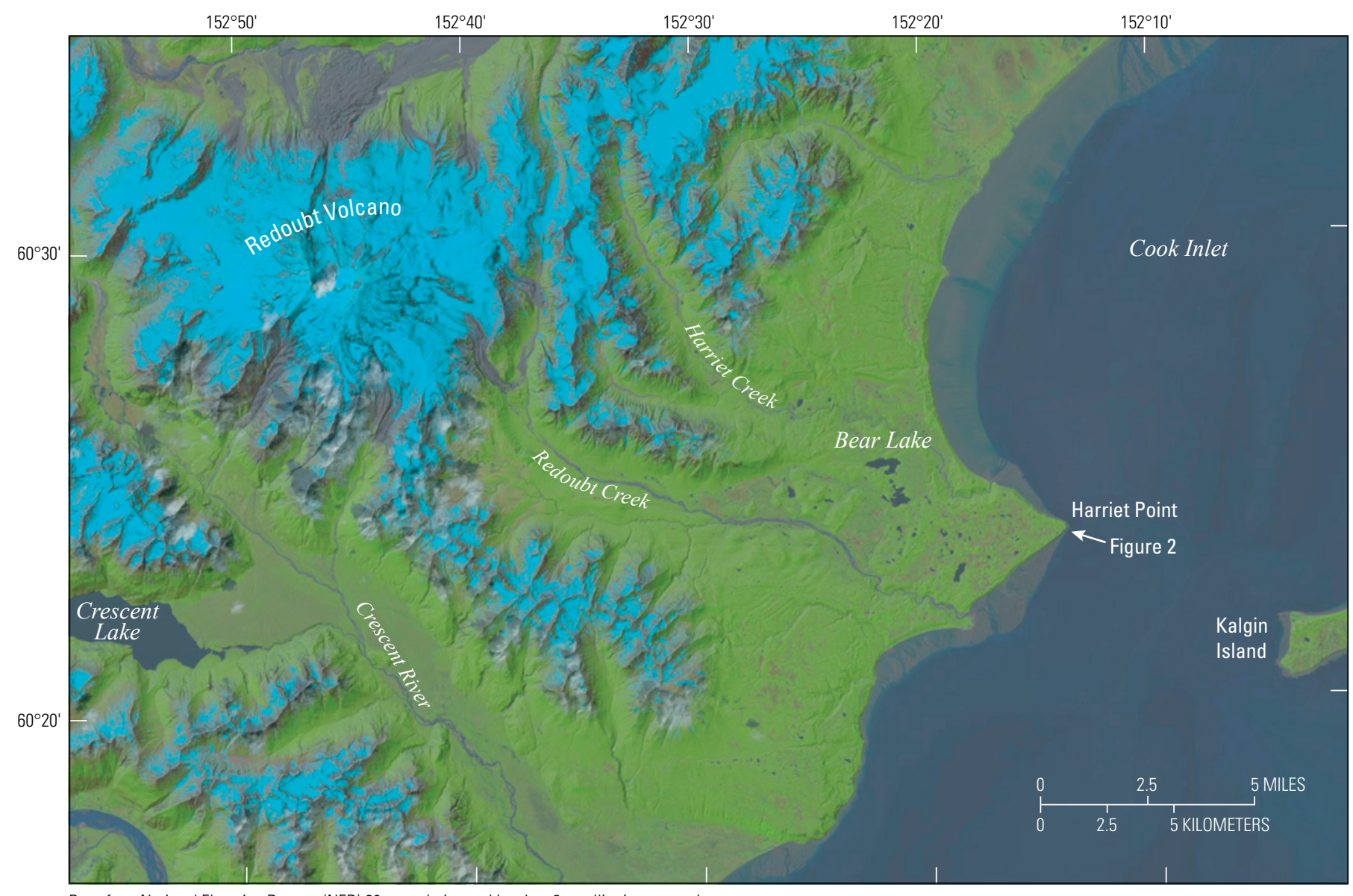

Base from National Elevation Dataset (NED) 60m resolution and Landsat 8 satellite image overlay Alaska Albers Equal-Area Conic projection, North American Datum of 1983
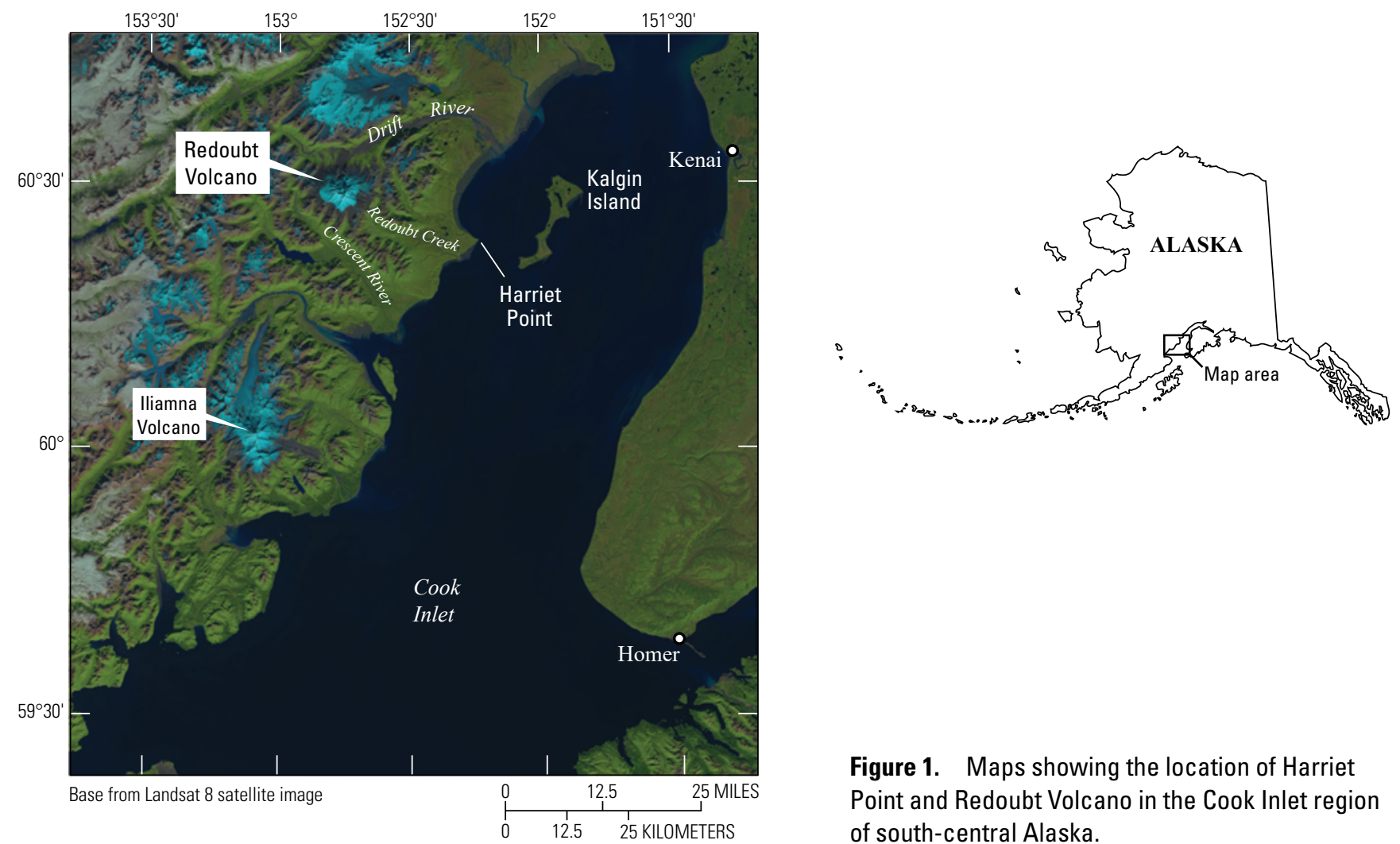

Figure 1. Maps showing the location of Harriet Point and Redoubt Volcano in the Cook Inlet region of south-central Alaska. 

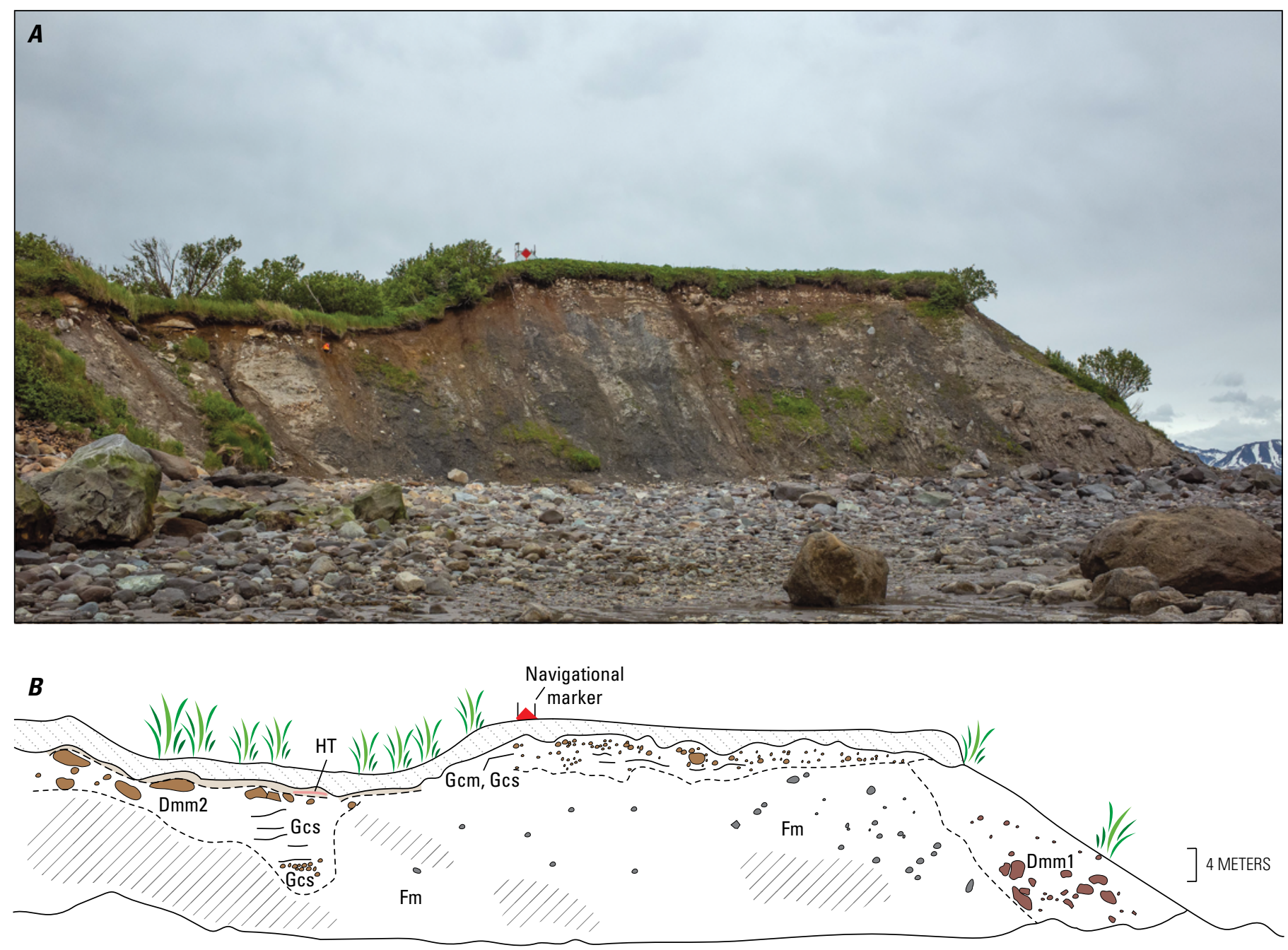

\begin{tabular}{|llll|}
\hline \multicolumn{3}{|c|}{ EXPLANATION } \\
Dmm & Gravel, massive, matrix supported & $\square$ & Eolian deposits with volcanic ash \\
Gcs & Gravel, clast supported, stratified & $\square$ & Covered \\
Gcm & Gravel, clast supported, massive & $\square$ & Modern vegetation mat \\
Fm & Fine sediment, massive & 0 & Cobbles, boulders \\
HT & Hayes tephra & $\square$ & Stratification \\
\hline
\end{tabular}

Figure 2. Photograph $(A)$ and sketch $(B)$ showing sea bluff exposure at Harriet Point on the west side of Cook Inlet near Redoubt Volcano. Photograph $(A)$ shows person in orange near top of middle left part of bluff for scale. Sketch $(B)$ shows the main stratigraphic units exposed at Harriet Point. Lithofacies Dmm1 and Dmm2 are similar lithologically but Dmm1 deposits are older than Dmm2 deposits.
Harriet Point consist of several glacigenic lithofacies that are described below.

Unconsolidated deposits at Harriet Point contain cobbles and boulders derived from Redoubt Volcano and exposed bedrock in the upland terrain of the Redoubt Creek drainage (fig. 1). The main rock types at Harriet Point form a prominent boulder lag deposit at the base of the sea bluff (fig. 3). The primary lithologies are medium to dark gray-green and gray-maroon andesite and lesser amounts of dioritic rocks. These rocks were likely derived from Redoubt Volcano, the Early Jurassic Talkeetna Formation, and
Jurassic plutonic rocks (units Qv, Jtk, and Jqd, respectively, on fig. 4; Wilson and others, 2012).

The sequence of unconsolidated deposits exposed at Harriet Point consists of several distinct lithofacies types. To facilitate field-based description of the deposits, a mnemonic lithofacies code modified from Eyles and others (1983) was used (table 1). The first letter of each code is capitalized and denotes the lithofacies. Fine-grained deposits that consist of some combination of silt, sand, and clay — but are mostly mud (silt and clay) — are denoted with the letter "F." Deposits that are poorly sorted 
Figure 3. Photograph showing unconsolidated deposits exposed at Harriet Point. The base of the outcrop contains an assemblage of lag boulders derived from wave erosion of the unconsolidated deposits exposed here. The largest boulders are 2 to 3 meters in length and consist primarily of gray-green to gray-maroon andesite.

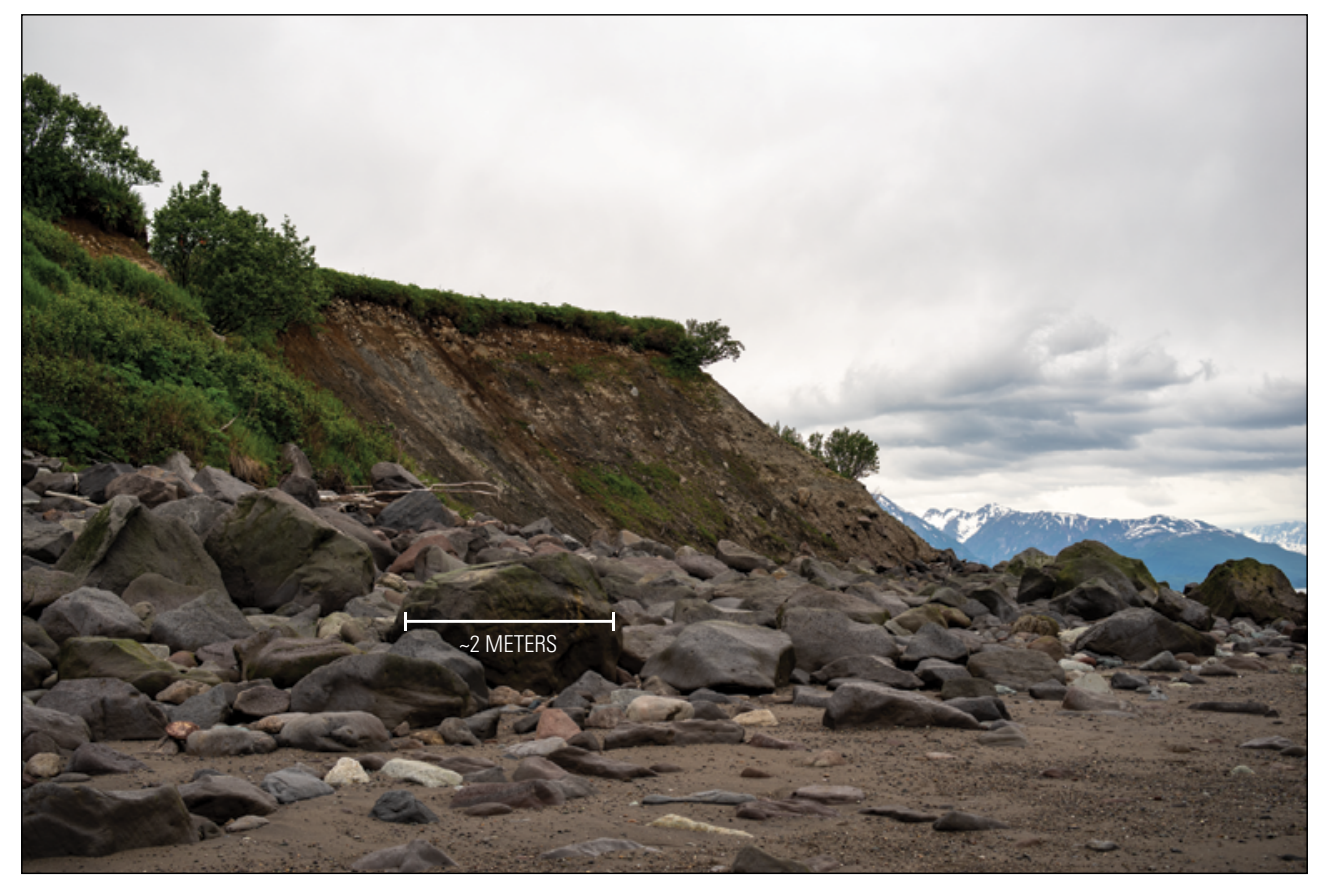

Table 1. Explanation of lithofacies code, modified from Eyles and others (1983).

\begin{tabular}{|c|c|c|}
\hline Lithofacies code & Lithofacies & Sedimentary structures \\
\hline $\mathrm{Fl}$ & Fine grained-mostly silt and clay (mud) & Laminated \\
\hline Fm & Fine grained — mostly silt and clay (mud) & Massive \\
\hline Dmm & $\begin{array}{l}\text { Diamict-poorly sorted mixture of sand, } \\
\text { silt, clay, cobbles, and boulders }\end{array}$ & Matrix supported, massive \\
\hline $\mathrm{Gcm}$ & Gravel_pebbles, cobbles, boulders & Clast supported, massive \\
\hline Ges & Gravel-pebbles, cobbles, boulders & Clast supported, stratified \\
\hline
\end{tabular}

mixtures of clasts, sand, and mud are denoted with the letter "D" in reference to the term diamict - a poorly sorted unconsolidated deposit consisting of cobbles, boulders, sand, and mud that can be either clast or matrix supported. Predominantly gravel deposits at Harriet Point are denoted by the letter "G." Additional, uncapitalized letters are used to indicate sedimentary structure(s) characteristic of each lithofacies (for instance, the " $\mathrm{m}$ " in the Fm lithofacies code refers to the massive nature of that lithofacies).

\section{Fm and FI Lithofacies}

The Fm lithofacies at Harriet Point consists of medium to dark gray, fissile, generally massive silt and clay (mud) with sporadic faint lamination and occasional matrix-supported cobbles, pebbles, and small boulders (figs. 2, 5). Deposits are designated Fl where they exhibit lamination (fig. 5). Some of the cobbles and small boulders are associated with downward sags in the mud-rich matrix, indicating that these clasts fell into fine-grained, deformable sediment. At Harriet Point, the Fm and Fl lithofacies constitute about 80 percent of the sea bluff exposure (fig. 2). The Fm lithofacies is also exposed in sea cliffs west and southwest of Harriet Point and can be traced inland along Redoubt Creek for several kilometers.

\section{Dmm1 Lithofacies}

The Dmm1 lithofacies consists of medium brown, poorly sorted, massive, matrix-supported diamicton with angular to subangular cobbles and boulders of andesite and scattered dioritic rocks (figs. 2, 6). Many of the cobbles and boulders are faceted, and surface striations are present on some clasts. Overall, this lithofacies is hard, compact, and difficult to excavate with a shovel. The matrix of the deposit is a mixture of silt, sand, and fine gravel that is mostly comminuted rock debris. The Dmm1 lithofacies has an abrupt, erosional contact with the Fm lithofacies and is younger than the Fm lithofacies.

\section{Dmm2 Lithofacies}

The Dmm2 lithofacies consists of orange brown, slightly oxidized, poorly sorted, mostly massive, matrix-supported gravel with angular to subangular cobbles and boulders of andesite and scattered dioritic rocks (figs. 2, 7). These deposits have a slightly greater content of sand and gravel than the Dmm1 lithofacies and are in gradational contact with associated Gcs and Gcm lithofacies deposits (fig. 7). 


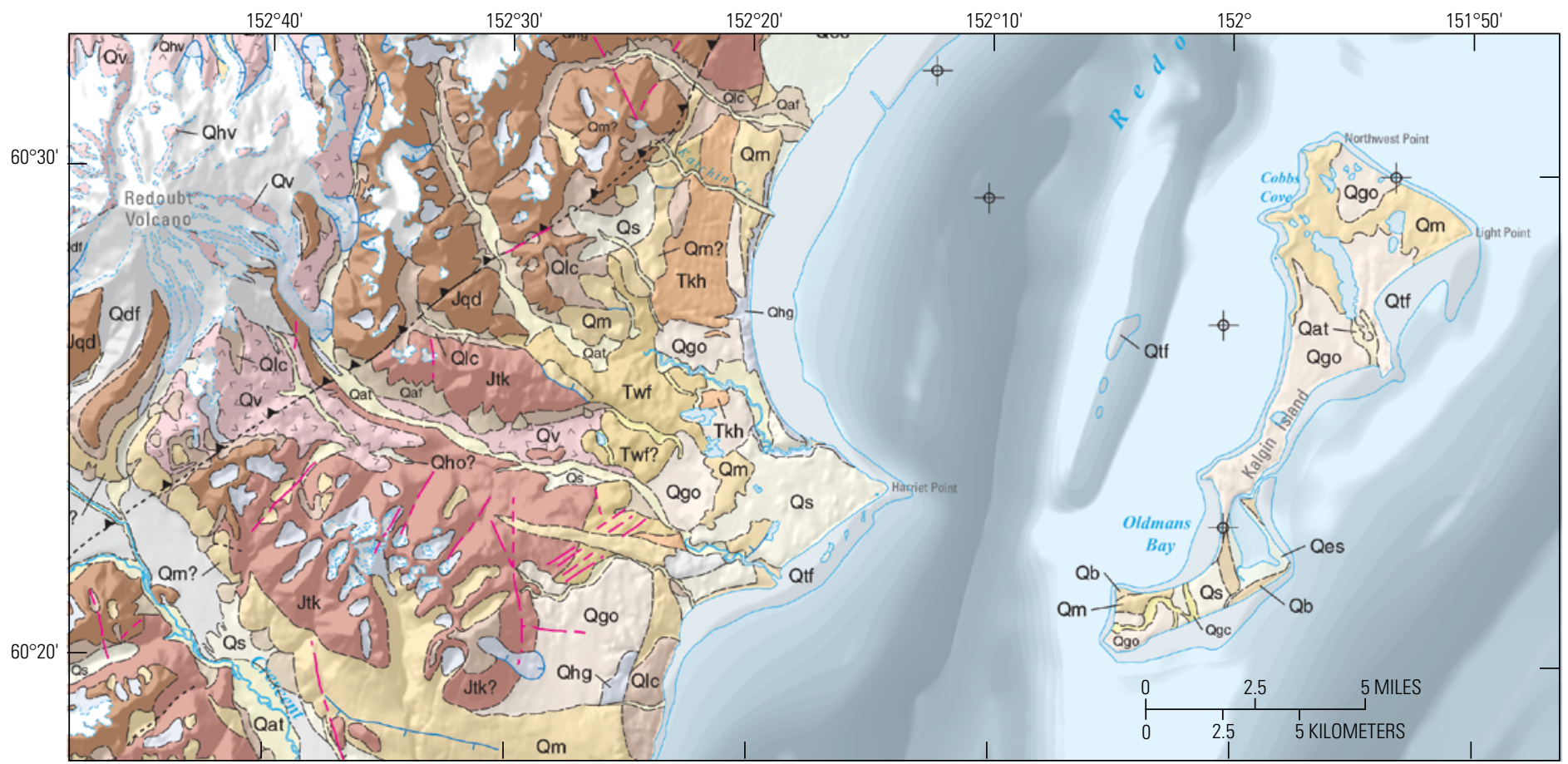

Shaded relief base from National Elevation Dataset (NED), $60 \mathrm{~m}$ resolution

\section{EXPLANATION}

\section{Surficial deposits}

Qs Surficial deposits, undivided (Quaternary)

Qat Alluvium along major rivers and in terraces (Holocene)

Qtf Modern tidal flat and estuarine deposits (Holocene)

Qes Estuarine deposits (Holocene)

Qaf Alluvial fan deposits (Holocene and upper Pleistocene)

Qdf Debris-flow deposits (Holocene)

Qlc Landslide and colluvial deposits (Holocene and upper Pleistocene)

$\mathrm{Qb}$ Beach deposits (Holocene)

Qhy Young moraine deposits (Holocene)

Qho Younger outwash deposits (Holocene)

Qm Major moraine and kame deposits (upper Pleistocene)

Qgc Glacioalluvium (upper Pleistocene)

Qgo Outwash in plains, valley trains, and fans (upper Pleistocene)

\section{Sedimentary rocks}

Tkh Hemlock Conglomerate, undivided (Oligocene)

Twf West Foreland Formation (Eocene and Paleocene)

Jtk Talkeetna Formation, undivided (Lower Jurassic)

\section{Igneous rocks}

$\hat{Q} v_{7}$ Volcanic rocks, undivided (Quaternary)

Qhv Volcanic rocks, undivided (Holocene)

Jqd Quartz diorite, tonalite, and diorite (Jurassic)

Dike-Dashed where inferred

1._._B Bruin Bay Fault-Solid where accurately located; dashed where inferred. Teeth on upthrown block.

$\oint \quad$ Plugged and abandoned well

Figure 4. Geologic map of the Redoubt Volcano-Harriet Point-Kalgin Island area of south-central Alaska from Wilson and others (2012). 
Figure 5. Photographs showing unconsolidated deposits exposed in the lower part of sea bluffs at Harriet Point. $A$, Photograph of base of bluff section at Harriet Point. $B$, Close-up view of Fm lithofacies that consists of clayey silt (pebbly mud) with dispersed subrounded to subangular pebbles (dropstones). Explanation of letters: $D$, dropstone; Fm, fine sediment (mainly silt and clay), massive; $\mathrm{Fl}$, fine sediment (mainly silt and clay), laminated; Gcs, fine gravel, clast supported, faintly stratified. Shovel in photograph is about 1.5 meters in length.
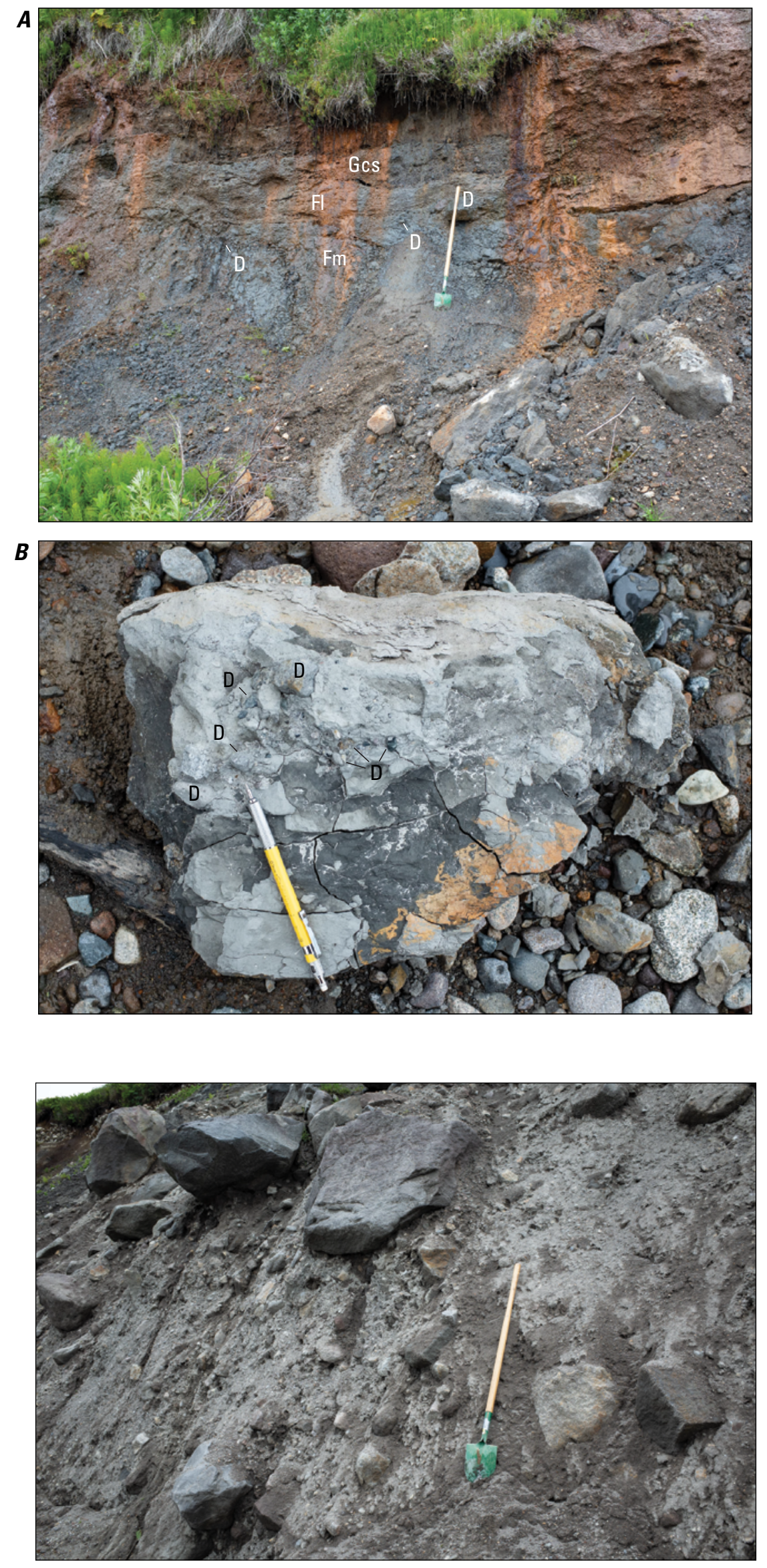

Figure 6. Photograph showing unconsolidated deposits of lithofacies Dmm1 at Harriet Point. See figure 2 for distribution of this lithofacies in the sea bluff at Harriet Point. Most of the clasts in the deposit consist of andesitic rocks (likely sourced from Redoubt Volcano and Talkeetna Formation bedrock) with a subordinate amount of dioritic rocks. Length of shovel in photograph is about 1.5 meters. 


\section{Gcm Lithofacies}

The Gcm lithofacies consists of clast-supported, massive, poorly sorted gravel deposits with slightly sandier textures than the Dmm lithofacies deposits described above (fig. 2). The Gcm lithofacies contains angular to subangular cobbles and boulders of andesite and subordinate amounts of dioritic rocks.

\section{Gcs Lithofacies}

The Gcs lithofacies consists of clast-supported, faintly stratified accumulations of sandy gravel with subangular to subrounded cobbles and small boulders of andesite and dioritic rocks (figs. 2, 7). Gcs lithofacies deposits are gradational with associated $\mathrm{Gcm}$ and Dmm2 lithofacies deposits but have an erosional basal contact with underlying Fm lithofacies deposits (figs. 2, 7).
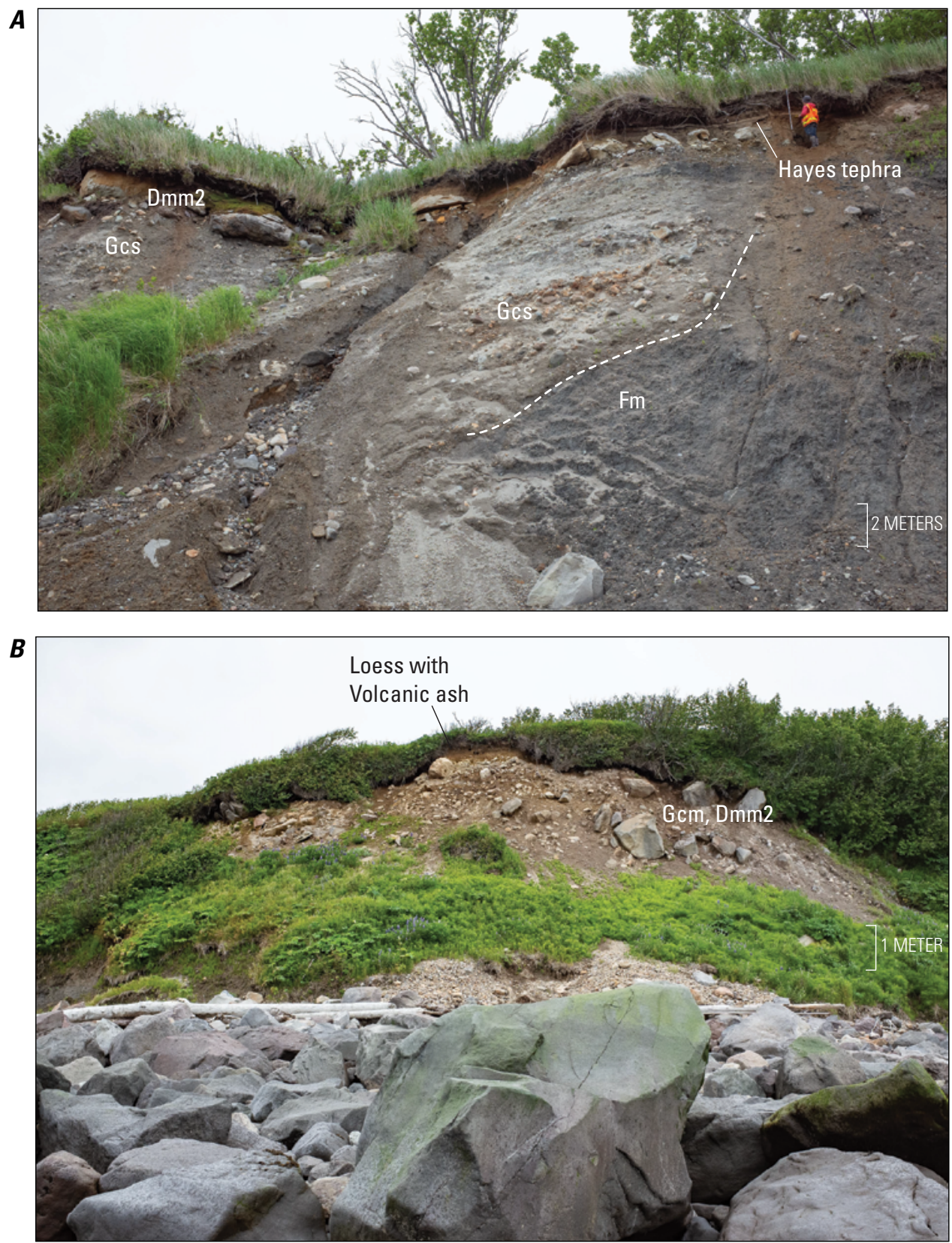

Figure 7. Photographs showing unconsolidated deposits exposed in the southern part of Harriet Point bluff. $A$, Upper part of bluff exposure showing Fm lithofacies deposits at base, unconformably overlain by Gcs lithofacies deposits. Gcs lithofacies deposits grade upward into Dmm2 lithofacies deposits. Note person at top of exposure for scale. $B$, Southernmost end of bluff exposure at Harriet Point, showing $\mathrm{Gcm}$ and $\mathrm{Dmm} 2$ lithofacies deposits overlain by oxidized loess deposits. Boulders in foreground are mostly gray andesite winnowed from the Harriet Point bluff by wave action. 


\section{Stratigraphy and Interpretation of Deposits at Harriet Point}

Four main stratigraphic units are preserved at Harriet Point (fig. 2) and are discussed according to their relative ages from oldest to youngest. The oldest unit consists entirely of Fm lithofacies deposits that are about $15 \mathrm{~m}$ thick and constitute about 80 percent of the deposits exposed at Harriet Point. The sedimentologic character of the Fm lithofacies indicates that it was the product of either glacioestuarine or glaciomarine deposition; the pebbles and cobbles in the unit are likely ice-rafted detritus (dropstones). It was not possible to make a concerted search for fossils in the unit that might indicate a marine versus freshwater depositional environment. However, the muddy, laminated character of these deposits indicates iceproximal deposition in water (Smith and Andrews, 2000; Powell and Domack, 2002).

The second main unit consists entirely of Dmm1 lithofacies deposits that are 15 to $20 \mathrm{~m}$ thick and found only at the apex of Harriet Point (fig. 2). The hard, compact nature of these deposits and their massive, boulder rich character indicates that they are glacial diamicton deposits (likely basal till or lodgement till).

Both the Fm and Dmm1 deposits are overlain by Gcs, Gcm, and Dmm2 lithofacies deposits, which together make up the third main unit at Harriet Point. The lithofacies assemblage includes basal ice-contact deposits (Dmm2) and ice-stagnation drift (Gcs, $\mathrm{Gcm}$ ) associated with a downwasting lobe of glacier ice that covered the area. In most places, the lithofacies assemblage of Gcs, Gcm, and Dmm2 are in erosional contact with the underlying Fm and Dmm1 lithofacies deposits indicating that the Gcs deposits may be advance outwash, or possibly glacigenic mass-flow deposits in turn overlain by ice-contact deposits.

The fourth and youngest stratigraphic unit at Harriet Point is a 1- to 2-m-thick sequence of eolian silt deposits (loess) that contain several fine volcanic ash layers - including the "Hayes tephra," a regional stratigraphic marker of middle Holocene age (Riehle and others, 1990; Wallace and others, 2014). These deposits also include several weakly developed buried soils with $\mathrm{Bw}$ and (or) Cox horizons. Soil development on the loess parent material has imparted an orange-brown color to the deposits, and this weathered loess and soil, where reworked over the bluff face, gives the appearance of altered material in the upper part of the bluff (figs. 2, 7).

\section{Depositional Model for Harriet Point Deposits}

A new interpretation of the main sequence of unconsolidated deposits exposed at Harriet Point is that the deposits and associated lithofacies are all glacigenic in origin. The bluff top eolian deposits may be periglacial deposits but the volcanic ash layers are unrelated to glaciation. As such, the Harriet Point deposits must be reconciled within the established glacial geologic framework for Cook Inlet (Karlstrom, 1964; Schmoll and Yehle, 1986; Reger and Pinney, 1996; Reger and others, 2007; Kopczynski and others, 2017).

A four-part model of late Quaternary glaciation of the Cook Inlet region was initially proposed by Karlstrom (1964). The basis for his explanation of late Quaternary glaciation are the moraines, outwash deposits, and other glacial features preserved on the Kenai Peninsula, primarily in and around the modern town of Sterling. At the time of his work, Sterling was known as Naptowne, and Karlstrom (1964) named the last major glaciation in the area the Naptowne glaciation. Karlstrom (1964) made a compelling argument that the Naptowne glaciation was broadly correlative with the classical late Wisconsin glaciation of midcontinent North America (Porter and Wright, 1983; Ehlers and others, 2011). According to Karlstrom (1964), the Naptowne glaciation is subdivided into four glacial stades, Moosehorn (oldest), Killey (intermediate), Skilak (younger), and Tanya (youngest). More recent studies have reassessed Karlstrom's model and offered important refinements through improved mapping and geochronology (Schmoll and others, 1972; Schmoll and others, 1984; Reger and Updike, 1983). The most important revision was the recognition of a late Naptowne glacier readvance in the Anchorage area known as the Elmendorf stade which is now accepted as the youngest stade of the Naptowne glaciation and supersedes the Tanya stade (Reger and Pinney, 1996; Schmoll and others, 1999; Kopczynski and others, 2017)

The most current chronology of Cook Inlet glacial events is described by Reger and others (2007) and Kopczynski and others (2017). According to these sources, the Moosehorn stade began about 32,000 to 27,000 calibrated years before present (cal. yr B.P.) and reached a maximum ice extent by about 23,000 cal. yr B.P. During the Moosehorn stade, glacier ice expanded from alpine areas, coalesced, and formed an extensive ice sheet over much of south-central Alaska that was contiguous with the northwestern sector of the Cordilleran ice sheet (Booth and others, 2004; Kaufman and others, 2011; Stroeven and others, 2014). At this time the Harriet Point area was under thick ice cover and the region was isostatically depressed (fig. $8 A$ ). During the waning phase of the Moosehorn stade, melting and receding glacier ice led to the development of meltwater lakes, some of which may have evolved to calving bays possibly influenced by tidewater (fig. $8 B$ ). Coastal bluff exposures of estuarine deposits along the south shore of Cook Inlet near Kenai, Alaska, contain calcareous barnacle plates that gave a radiocarbon age of $16,480 \pm 170 \mathrm{yr}$ B.P. (19,200 cal. yr B.P.) (Reger and others, 1996). The presence of barnacle plates at this location indicates that marine water had reached the Kenai area by 19,200 cal. yr B.P. and that lower Cook Inlet was no longer blocked by glacier ice (Reger and others, 2007).

The Killey stade was a relatively short-lived ice advance 18,500 to 17,500 cal. yr B.P. (Reger and others, 2007) that produced prominent morainal belts that enclose Tustumena and Skilak Lakes and an ice advance that extended across Cook Inlet from north to south over the area north of Kenai (fig. 8B). The Killey stade ice margin in the vicinity of Harriet Point is uncertain but could have been just beyond Kalgin Island (fig. $8 B$ ). 

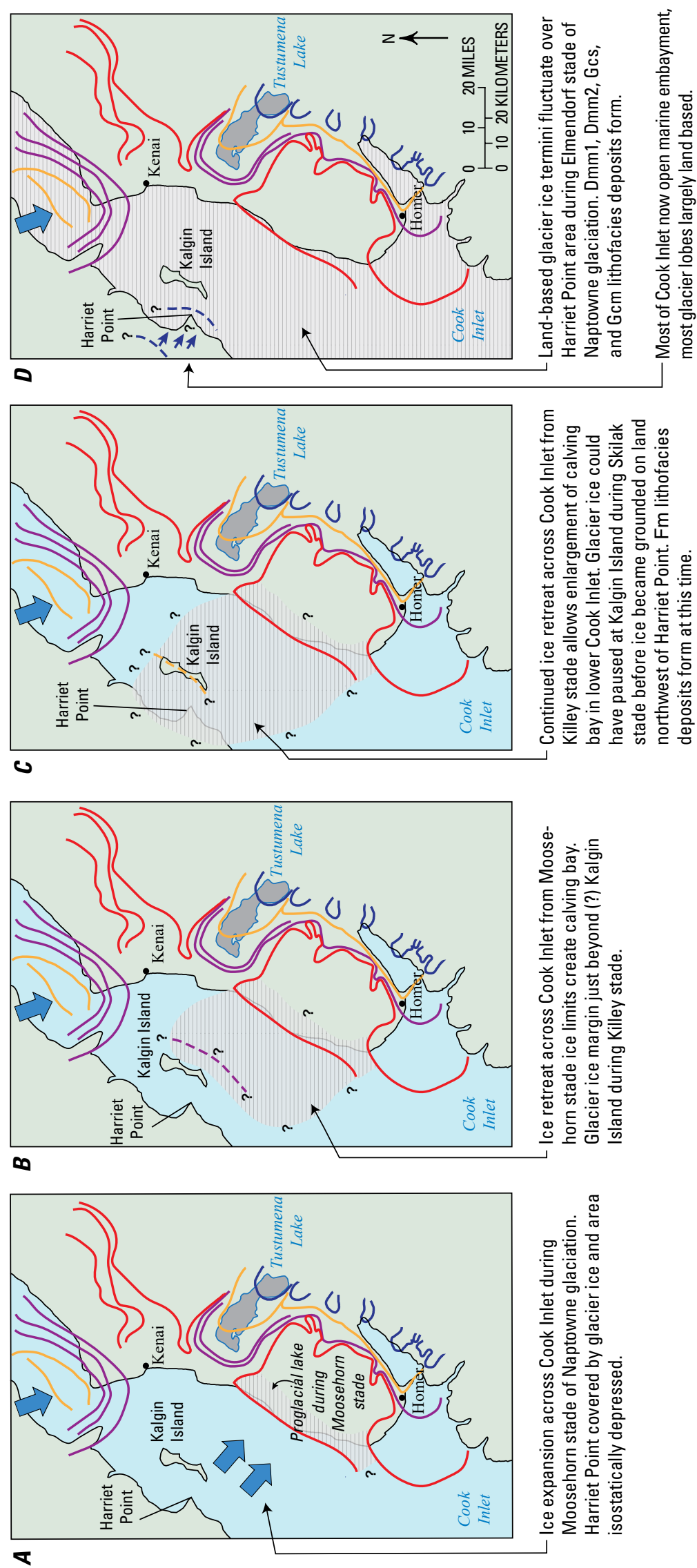

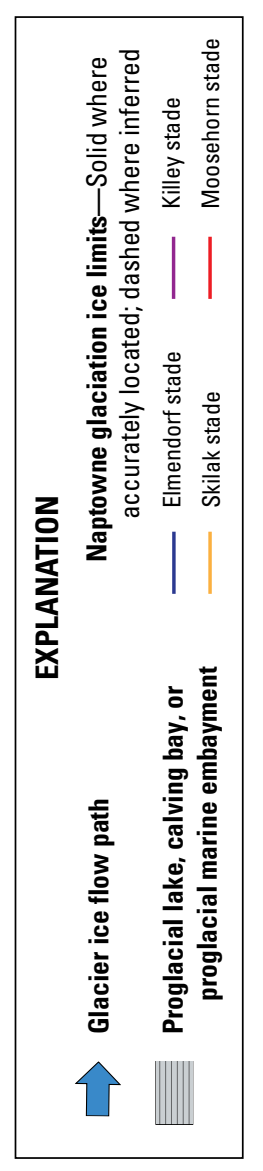

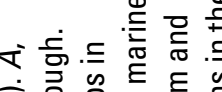
穴옹응 完 w

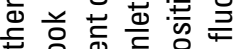

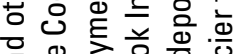
它 के ब잉 (1) 일 要 范

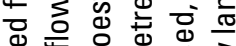
泣事

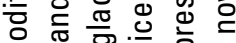
E $\bar{\Phi}$ 증

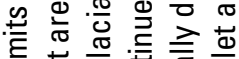
声

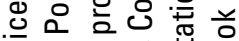
屯. 语 픔 종

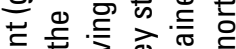

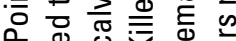

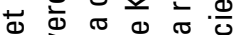

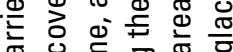
조 00 을

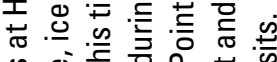
电定

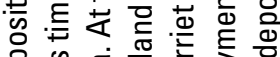

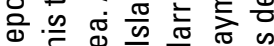
음 흐을 응

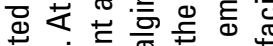

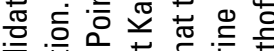
음 음 운 次 은

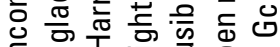
ऽ

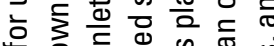

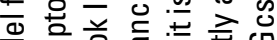

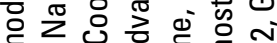
ह

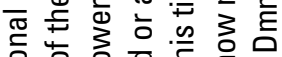

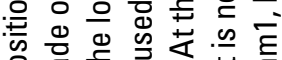
응 元 岳 元它

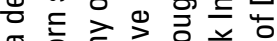

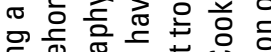

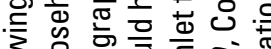

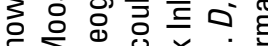
क $\sum$ व E 일. 흔

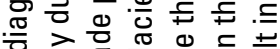
흘 중 음 क 苋

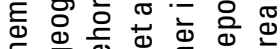
额品 $\infty$ 元 $\sum_{1}^{0} \frac{0}{0}$ o.

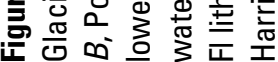


During the Skilak stade of the Naptowne glaciation $(17,500$ 16,000 cal. yr B.P), ice lobes no longer blocked Cook Inlet and marine waters extended into the upper part of the Cook Inlet basin (Reger and others, 1995; Reger and others, 2007). Large outlet glaciers reaching Cook Inlet from the north had calving, shallowmarine margins that led to the development of the Bootlegger Cove Formation, a fossil-bearing glacioestuarine unit composed of clay, silt, and sand with abundant dropstones that underlies drift associated with the Elmendorf stade (Reger and others, 1995; Kopczynski and others, 2017). The Fm and Fl lithofacies deposits at Harriet Point possibly developed at this time when the area remained isostatically depressed and at or just beyond the local limits of Skilak stade glacier ice (fig. 8C). Kalgin Island, an arcuate-shaped partly submerged morainal complex within Cook Inlet, possibly marks the limit of glacier ice during the Skilak stade (fig. 8C).

The final stade of the Naptowne glaciation, the Elmendorf stade, is named for a prominent set of nested moraines just north of Anchorage (Reger and others, 1995; Reger and others, 2007; Kopczynski and others, 2017). During the Elmendorf stade, valley glaciers advanced from the northern Kenai and Chugach Mountains into the adjacent lowlands to form prominent knoband-kettle terminal moraines and a recessional sequence of ice-disintegration drift (Reger and Updike, 1983; Reger and others, 1995; Kopczynski and others, 2017). According to Reger and others (2007), the age of the Elmendorf stade is about 15,000 to $11,000 \mathrm{cal}$. yr B.P. A recent reanalysis of the radiocarbon chronology for the Elmendorf stade indicates that the climax of the stadial advance occurred 16,800 to 16,000 cal. yr B.P. (Richard D. Reger, Reger's Geologic Consulting, written commun., 2020). Ice possibly advanced over the Harriet Point area during the Elmendorf stade (fig. $8 D$ ) and may have been responsible for generating the Dmm1 lithofacies. Downwasting of Elmendorf stade ice at Harriet Point likely generated ice stagnation drift (Dmm2 and Gcm lithofacies) and outwash (Gcs lithofacies) as well. The arcuate terminal moraines and ice-stagnation drift in lower Redoubt Creek are indicative of late Elmendorf stade ice retreat in the Redoubt Creek drainage (fig. 9). These deposits encompass several kettle lakes, one of which (Bear Lake, fig. 9) was cored several times and found to contain a long Holocene record of lacustrine sediment and volcanic ash accumulation (Schiff and others, 2010). The oldest deposits in Bear Lake (core BL-7) are about 12,000 cal. yr B.P., indicating that ice retreat from the area occurred prior to that time, which is in general agreement with a late Elmendorf stade age for deglaciation of the Harriet Point area.

Although dating and correlation of moraines and other glacial features in the Harriet Point area (fig. 9) to the established model of Naptowne glaciation elsewhere in the Cook Inlet region awaits further study, the proposed explanation (fig. 8) is a plausible starting point and can be tested with additional fieldwork.

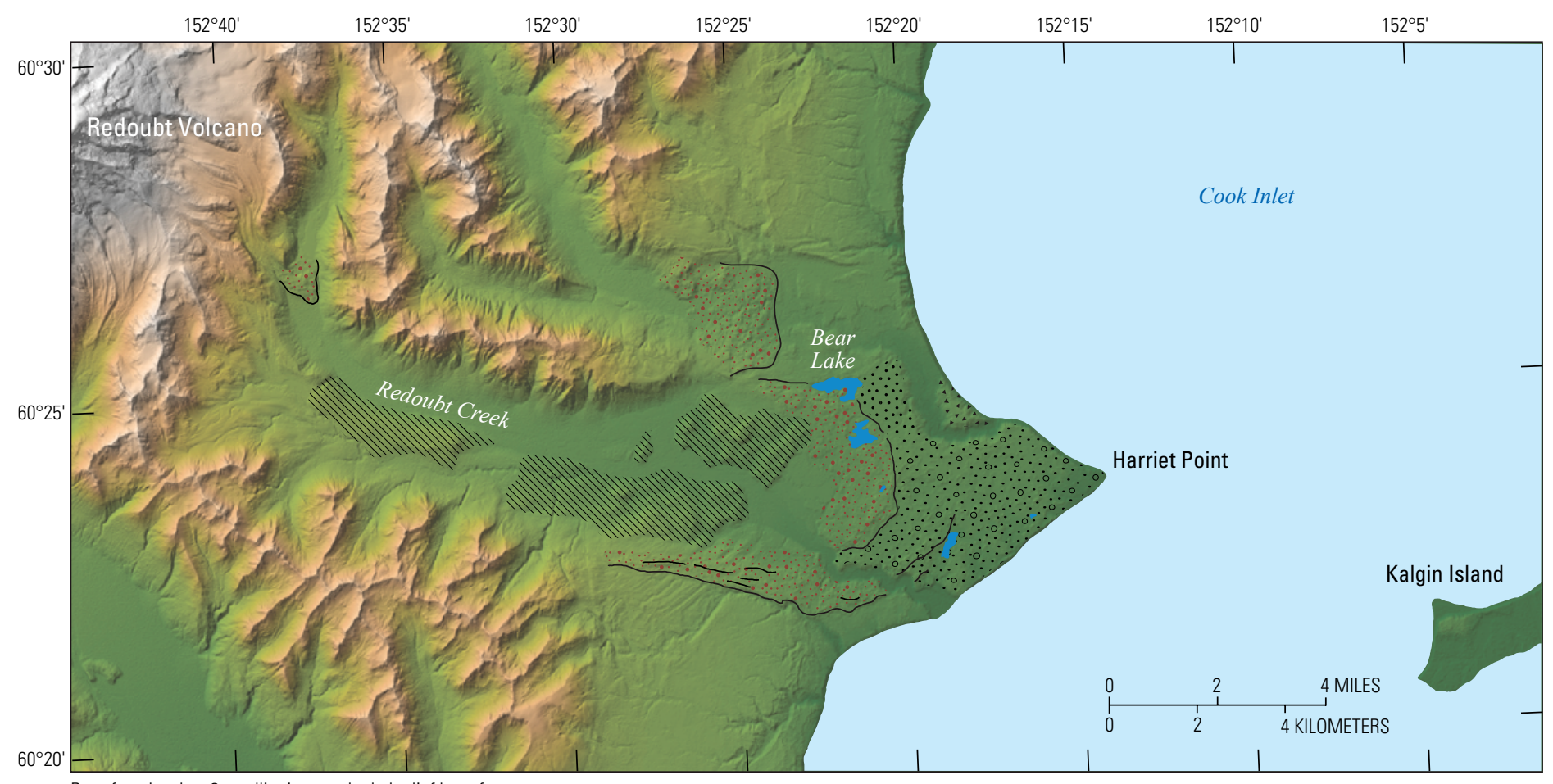

Base from Landsat 8 satellite image; shaded relief base from National Elevation Dataset (NED), $60 \mathrm{~m}$ resolution
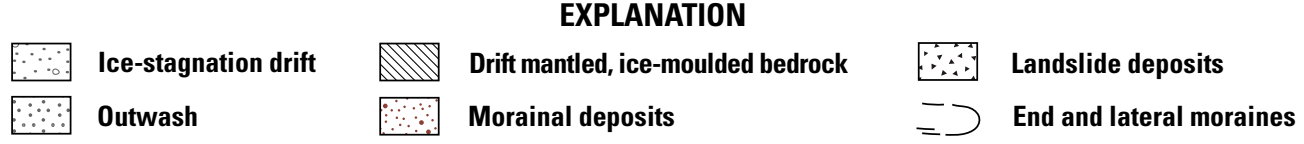

Figure 9. Map of glacial deposits and landforms in the Redoubt Creek-Harriet Point area. A lake core from Bear Lake has a basal radiocarbon age of about 12,000 calibrated years before present, indicating that glacier ice had retreated from the area by that time and implying that the glacial deposits in the Harriet Point area are of Elmendorf stade (Naptowne glaciation) age. 


\section{Reevaluation of Harriet Point Debris- Avalanche Deposit}

As described above, the areal extent and minimum volume (0.04-0.2 km $\mathrm{km}^{3}$ of the Harriet Point debris-avalanche deposit of Begét and Nye (1994) indicates a small but notable flank collapse on the southeast flank of Redoubt Volcano. The resulting debris avalanche would remove as much as 6 percent of the modern edifice, which then regrew to the present-day configuration in about 10,000 years. Removal of $0.2 \mathrm{~km}^{3}$ of material from the edifice of Redoubt Volcano would require a minimum eruptive rate of $0.02 \mathrm{~km}^{3}$ per thousand years $\left(\mathrm{km}^{3} / \mathrm{ky}\right)$ to restore the edifice volume by that amount, assuming that the volcano began rebuilding about 10,000 years ago.

Short-term eruptive rates are not well known for stratovolcanoes in the Aleutian arc. However, Klyuchevskoy Volcano on the Kamchatka Peninsula is similar to many volcanoes in the Aleutian arc, and has an eruptive rate estimated in the range of 22 to $32 \mathrm{~km}^{3} / \mathrm{ky}$ (Fedotov and others, 1987). The ice- and snow-clad Klyuchevskoy is one of the most active volcanoes in the world and likely represents an upper bound for the eruptive rates of islandarc stratovolcanoes. In one of the few Alaska studies to address short-term eruptive rates, Jicha and Singer (2006) report that the average eruptive rate across all vents at Seguam volcano ${ }^{1}$ over the

${ }^{1}$ The informal name "Seguam volcano" is used here because the official volcanic name, Pyre Peak, does not coincide with the full geographic or geologic extent of the volcano (Seguam volcano comprises multiple vents — of which Pyre Peak is only one). past 9,000 years was $1.2 \mathrm{~km}^{3} / \mathrm{ky}$, but rates as high as $4.7 \mathrm{~km}^{3} / \mathrm{ky}$ over a similar period were estimated for one of the main basaltic cones on Seguam Island. At Akutan Island, in the central Aleutian Islands, Holocene eruptive rates are much lower, on the order of $0.3 \mathrm{~km}^{3} / \mathrm{ky}$ (Coombs and Jicha, 2021). The average long-term (from 3.5 million years ago [Ma] to the present) eruptive rate for the Aleutian arc has been estimated by Marsh (1982) and Crisp (1984), who gave rates of $1.6 \mathrm{~km}^{3} / \mathrm{ky}$ and $2.1 \mathrm{~km}^{3} / \mathrm{ky}$, respectively. In the Cascade Range, Quaternary extrusion rates as high as 2 to $5 \mathrm{~km}^{3} / \mathrm{ky}$ were estimated for Mount Adams, and about $2 \mathrm{~km}^{3} / \mathrm{ky}$ for Mount St. Helens (Sherrod and Smith, 1990). In the context of these reported values, eruptive rates at Redoubt Volcano on the order of $0.02 \mathrm{~km}^{3} / \mathrm{ky}$ are certainly plausible.

The areal extent of the Harriet Point debris-avalanche deposit of Begét and Nye (1994) is reported as covering an area of 40,000,000 square meters $\left(\mathrm{m}^{2}\right)$, and if (as described above) the deposit has a thickness of 1 to $5 \mathrm{~m}$, then the corresponding volume would be 0.04 to $0.2 \mathrm{~km}^{3}$. A functional relation between landslide area of inundation and landslide volume as implemented in the computational model LAHARZ (Schilling, 1998; Griswold and Iverson, 2008) was used to simulate areas on the southeast flank of Redoubt Volcano in the Redoubt Creek drainage that would be inundated by volcanic landslides with volumes in the range of 0.04 to $0.2 \mathrm{~km}^{3}$. LAHARZ is based on calibrated power-law equations of the form $A=c V^{2 / 3}$, relating flow volume ( $V$ ) to planimetric area of inundation $(A)$ for a mass flow as it exits a predefined proximal zone (height/length $=0.3$ on fig. 10 ) and spreads downstream within the drainage of interest

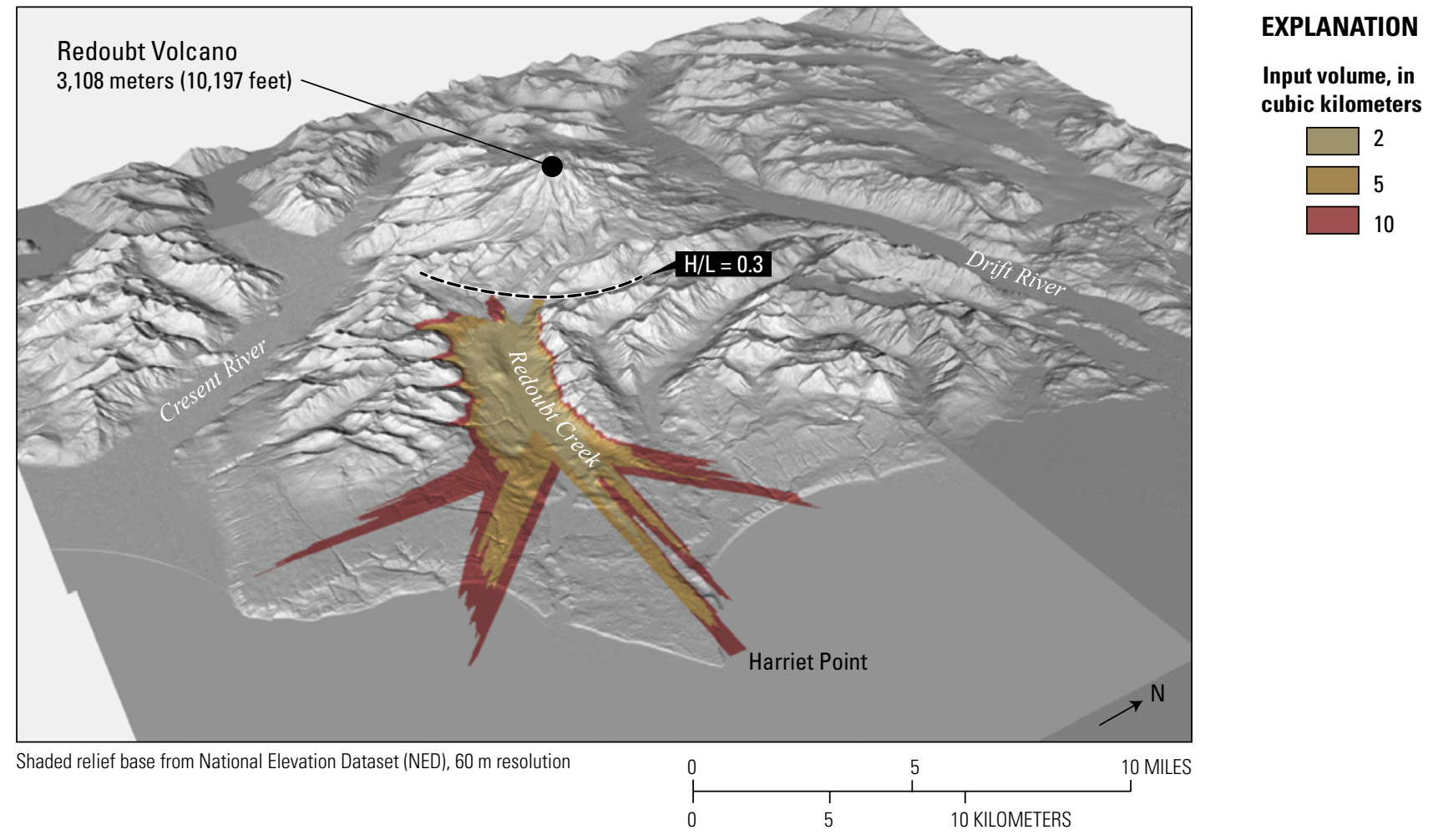

Figure 10. Image showing inundation of the Redoubt Creek drainage by volcanic landslides estimated with the numerical model LAHARZ (Schilling, 1998; Griswold and Iverson, 2008). The simulation results indicate that a volcanic landslide with a volume greater than 5 cubic kilometers would be required to inundate the Harriet Point area. H/L, height to length. 
(Iverson and others, 1998). Best-fit values of the coefficient $c$ are determined from logarithmic transformation and linear regression of mass-flow inundation area and volume data. A specific mass-flow volume is used as initial input to the LAHARZ model, and the corresponding area of inundation is portrayed on a digital elevation model of the topography for the region of interest.

LAHARZ simulations of volcanic landslides in the Redoubt Creek drainage (fig. 10) indicate that landslides with volumes in excess of 5 to $10 \mathrm{~km}^{3}$ would be required to match the extent of the Harriet Point debris-avalanche deposit of Begét and Nye (1994). An avalanche with a volume of 0.04 to $0.2 \mathrm{~km}^{3}$ would have a very restricted inundation area limited to the upper part of the Redoubt Creek drainage and, at this volume, could not reach Harriet Point.

\section{Summary}

Field-based stratigraphic and sedimentologic analysis of deposits exposed at Harriet Point southwest of Redoubt Volcano indicate a sequence of glaciomarine or glacioestuarine deposits overlain by glacial deposits that may be of Elmendorf stade age. The origin of the deposits at Harriet Point have been reinterpreted and there is no compelling evidence that any of the unconsolidated deposits exposed there originated by volcanic mass-flow processes. The "Harriet Point debris-avalanche deposit" of Begét and Nye (1994) is a massive, matrix-supported diamicton that locally has an apparent orange cast. The orange appearance is caused by a thin surface cover of slightly oxidized reworked loess that extends over the bluff face from its bluff top location. Thus, the apparent orange color of the deposit in some locations is unrelated to the presence of altered volcanic material, which was not observed at the Harriet Point outcrop. Simulations of volcanic landslide inundation of the Redoubt Creek drainage using initial landslide volumes of 2,5 , and $10 \mathrm{~km}^{3}$ do not produce an area of inundation that matched the previously asserted extent of the Harriet Point debris-avalanche deposit, and no physical basis exists for extensive runout of the Harriet Point debris avalanche. Volcanic debris-avalanche deposits greater than $1 \mathrm{~km}^{3}$ are typically associated with major sector collapse events that characteristically produce prominent and long-lasting horseshoe-shaped scars on the truncated edifice (Voight and others, 1983; Siebert, 1984; Capra and others, 2002; Ponomareva and others, 2006). Thus, a debris avalanche originating on the southeast flank of Redoubt Volcano and capable of reaching Harriet Point would be expected to have left a failure scar, but no such feature has been observed or documented. The sedimentologic character and sequence of deposits exposed at Harriet Point are consistent with the interpretation that these deposits are primarily glacial in origin and can be explained in the context of late Quaternary deglaciation of the Cook Inlet area.

\section{Acknowledgments}

Assistance in the field was ably provided by K. Wallace and H. Dietterich. An earlier version of the manuscript was reviewed by R.D. Reger and J.R. Schaefer whose comments and suggestions improved the clarity and readability of the manuscript. Timothy Herold provided a skilled edit and offered many helpful suggestions.

\section{References Cited}

Begét, J.E., and Nye, C.J., 1994, Postglacial eruption history of Redoubt Volcano, Alaska: Journal of Volcanology and Geothermal Research, v. 62, no. 1, p. 31-54, https://doi. org/10.1016/0377-0273(94)90027-2.

Booth, D.B., Troost, K.G., Clague, J.J., and Waitt, R.B., 2004, The Cordilleran ice sheet, in Gillespie, A.R., Porter, S.C., and Atwater, B.F., eds., The Quaternary Period in the United States: Developments in Quaternary Sciences, v. 1, p. 17-43.

Capra, L., Macias, J.L., Scott, K.M., Abrams, M., and GarduñoMonroy, V.H., 2002, Debris avalanches and debris flows transformed from collapses in the Trans-Mexican Volcanic Belt, Mexico - Behavior, and implications for hazard assessment: Journal of Volcanology and Geothermal Research, v. 113, nos. 1-2, p. 81-110, https://doi.org/10.1016/ S0377-0273(01)00252-9.

Coombs, M.L., and Jicha, B.R., 2021, The eruptive history, magmatic evolution, and influence of glacial ice at long-lived Akutan volcano, eastern Aleutian Islands, Alaska, USA: Geological Society of America Bulletin, v. 133, no. 5-6, p. 963-991, https://doi.org/10.1130/B35667.1.

Crisp, J.A., 1984, Rates of magma emplacement and volcanic output: Journal of Volcanology and Geothermal Research, v. 20, nos. 3-4, p. 177-211, https://doi.org/10.1016/03770273(84)90039-8.

Ehlers, J., Gibbard, P.L., and Hughes, P.D., eds., 2011, Quaternary glaciations-Extent and chronology, a closer look: Developments in Quaternary Sciences, v. 15, 1,126 p.

Eyles, N., Eyles, C.H., and Miall, A.D., 1983, Lithofacies types and vertical profile models; an alternative approach to the description and environmental interpretation of glacial diamict and diamictite sequences: Sedimentology, v. 30, p. 393-410, https://doi.org/10.1111/j.1365-3091.1983.tb00679.x.

Fedotov, S.A., Khrenov, A.P., and Jarinov, N.A., 1987, Klyuchevskoy Volcano-Its activity and evolution, 1932-1986: Vulkanologiya i Seysmologiya, v. 4, p. 3-16. 
Griswold, J.P., and Iverson, R.M., 2008, Mobility statistics and automated hazard mapping for debris flows and rock avalanches: U.S. Geological Survey Scientific Investigations Report 2007-5276, 59 p., https://pubs.usgs. gov/sir/2007/5276/.

Iverson, R.M., Schilling, S.P., and Vallance, J.W., 1998, Objective delineation of lahar-inundation hazard zones: Geological Society of America Bulletin, v. 110, no. 8, p. 972-984, https:// doi.org/10.1130/0016-7606(1998)110<0972:ODOLIH $>2.3$ .CO;2.

Jicha, B.R., and Singer, B.S., 2006, Volcanic history and magmatic evolution of Seguam Island, Aleutian Island arc, Alaska: Geological Society of America Bulletin, v. 118, no. 7-8, p. 805-822, https://doi.org/10.1130/B25861.1.

Karlstrom, T.N., 1964, Quaternary geology of the Kenai lowland and glacial history of the Cook Inlet region, Alaska: U.S. Geological Survey Professional Paper 443, 69 p., 6 sheets, various scales, https://doi.org/10.3133/pp443.

Kaufman, D.S., Young, N.E., Briner, J.P., and Manley, W.F., 2011, Alaska palaeo-glacier atlas (version 2): Developments in Quaternary Sciences, v. 15, p. 427-445, https://doi. org/10.1016/B978-0-444-53447-7.00033-7.

Kopczynski, S.E., Kelley, S.E., Lowell, T.V., Evenson, E.B., and Applegate, P.J., 2017, Latest Pleistocene advance and collapse of the Matanuska-Knik glacier system, Anchorage Lowland, southern Alaska: Quaternary Science Reviews, v. 156, p. 121-134, https://doi.org/10.1016/j. quascirev.2016.11.026.

Marsh, B.D., 1982, The Aleutians, in Thorpe, R., ed., Andesites-Orogenic andesites and related rocks: New York, Wiley, p. 99-114.

Miller, T.P., and Chouet, B.A., eds., 1994, The 1989-1990 eruptions of Redoubt Volcano, Alaska: Journal of Volcanology and Geothermal Research, v. 62, nos. 1-4, $530 \mathrm{p}$.

Ponomareva, V.V., Melekestsev, I.V., and Dirksen, O.V., 2006, Sector collapses and large landslides on Late PleistoceneHolocene volcanoes in Kamchatka, Russia: Journal of Volcanology and Geothermal Research, v. 158, nos. 1-2, p. 117-138, https://doi.org/10.1016/j.jvolgeores.2006.04.016.

Porter, S.C., and Wright, H.E., eds., 1983, Late Quaternary Environments of the United States, volume 1-The late Pleistocene: Minneapolis, University of Minnesota Press, 407 p.

Powell, R., and Domack, G.W., 2002, Modern glaciomarine environments, in Menzies, J., ed., Modern and past glacial environments: Oxford, U.K., Butterworth-Heinemann, p. 361-389.
Reger, R.D., and Updike, R.G., 1983, Upper Cook Inlet and Matanuska Valley, in Péwé, T.L., and Reger, R.D., eds., Guidebook to permafrost and Quaternary geology along the Richardson and Glenn Highways between Fairbanks and Anchorage, Alaska: Alaska Division of Geological and Geophysical Surveys Guidebook 1, p. 185-263, 1 sheet, scale 1:250,000, https://doi.org/10.14509/263.

Reger, R.D., Combellick, R.A., and Brigham-Grette, J., 1995, Late-Wisconsin events in the upper Cook Inlet region, south-central Alaska, in Combellick, R.A., ed., Short notes on Alaska geology 1995: Alaska Division of Geological and Geophysical Surveys Professional Report 117D, p. 33-45, https://doi.org/10.14509/2320.

Reger, R.D., Pinney, D.S., Burke, R.M., and Wiltse, M.A., 1996, Catalog and initial analyses of geologic data related to Middle to Late Quaternary deposits, Cook Inlet region, Alaska: Alaska Division of Geological and Geophysical Surveys Report of Investigations 95-6, 188 p., 5 sheets, scale 1:250,000, https://doi.org/10.14509/2520.

Reger, R.D., and Pinney, D.S., 1996, Late Wisconsin glaciation of the Cook Inlet region with emphasis on Kenai lowland and implications for early peopling, in Davis, N.Y., and Davis, W.E., eds., Adventures through time-Readings in the anthropology of Cook Inlet, Alaska: Anchorage, Alaska, Cook Inlet Historical Society, p. 13-35.

Reger, R.D., Sturmann, A.G., Berg, E.E., and Burns, P.A.C., 2007, A guide to the late Quaternary history of northern and western Kenai Peninsula, Alaska: Alaska Division of Geological and Geophysical Surveys Guidebook 8, 112 p., 6 sheets, scale 1:25,000, https://doi.org/10.14509/15941.

Riehle, J.R., Bowers, P.M., and Ager, T.A., 1990, The Hayes tephra deposits, an upper Holocene marker horizon in southcentral Alaska: Quaternary Research, v. 33, no. 3, p. 276-290, https://doi.org/10.1016/0033-5894(90)90056-Q.

Schiff, C.J., Kaufman, D.S., Wallace, K.L., and Ketterer, M.E., 2010, An improved proximal tephrochronology for Redoubt Volcano, Alaska: Journal of Volcanology and Geothermal Research, v. 193, nos. 3-4, p. 203-214, https:// doi.org/10.1016/j.jvolgeores.2010.03.015.

Schilling, S.P., 1998, LAHARZ; GIS programs for automated mapping of lahar-inundation hazard zones: U.S. Geological Survey Open-File Report 98-638, 80 p., https://doi.org/10.3133/ ofr98638.

Schmoll, H.R., Szabo, B.J., Rubin, M., and Dobrovolny, E., 1972, Radiometric dating of marine shells from the Bootlegger Cove Clay, Anchorage area, Alaska: Geological Society of America Bulletin, v. 83, no. 4, p. 1107-1114. 
Schmoll, H.R., Yehle, L.A., Gardner, C.A., and Odum, J.K., 1984, Guide to the surficial geology and glacial stratigraphy in the upper Cook Inlet basin: Anchorage, Alaska Geological Society, $89 \mathrm{p}$.

Schmoll, H.R., and Yehle, L.A., 1986, Pleistocene glaciation of the upper Cook Inlet basin-A preliminary re-examination based on geologic mapping in progress, in Hamilton, T.D., Reed, K.M., and Thorson, R.M., eds., Glaciation in AlaskaThe geologic record: Anchorage, Alaska Geological Society, p. 193-218.

Schmoll, H.R., Yehle, L.A., and Updike, R.G., 1999, Summary of Quaternary geology of the municipality of Anchorage, Alaska: Quaternary International, v. 60, p. 3-36, https://doi. org/10.1016/S1040-6182(99)00004-X.

Shea, T., and van Wyk de Vries, B., 2008, Structural analysis and analogue modeling of the kinematics and dynamics of rockslide avalanches: Geosphere, v. 4, no. 4, p. 657-686, https://doi. org/10.1130/GES00131.1.

Sherrod, D.R., and Smith, J.G., 1990, Quaternary extrusion rates of the Cascade Range, northwestern United States and southern British Columbia: Journal of Geophysical Research, Solid Earth, v. 95 (B12), p. 19465-19474, https://doi.org/10.1029/ JB095iB12p19465.

Siebert, L., 1984, Large volcanic debris avalanchesCharacteristics of source areas, deposits, and associated eruptions: Journal of Volcanology and Geothermal Research, v. 22, nos. 3-4, p. 163-197, https://doi. org/10.1016/0377-0273(84)90002-7.
Smith, L.M., and Andrews, J.T., 2000, Sediment characteristics in iceberg dominated fjords, Kangerlussuaq region, East Greenland: Sedimentary Geology, v. 130, nos. 1-2, p. 11-25, https://doi.org/10.1016/S0037-0738(99)00088-3.

Stroeven, A.P., Fabel, D., Margold, M., Clague, J.J., and Xu, S., 2014, Investigating absolute chronologies of glacial advances in the NW sector of the Cordilleran ice sheet with terrestrial in situ cosmogenic nuclides: Quaternary Science Reviews, v. 92, p. 429-443, https://doi.org/10.1016/j. quascirev.2013.09.026.

Voight, B., Janda, R.J., Glicken, H., and Douglass, P.M., 1983, Nature and mechanics of the Mount St. Helens rockslideavalanche of 18 May 1980: Geotechnique, v. 33, no. 3, p. 243-273, https://doi.org/10.1016/0148-9062(83)90666-6.

Wallace, K.L., Coombs, M.L., Hayden, L.A., and Waythomas, C.F., 2014, Significance of a near-source tephra-stratigraphic sequence to the eruptive history of Hayes Volcano, south-central Alaska: U.S. Geological Survey Scientific Investigations Report 2014-5133, 32 p., https://pubs.usgs.gov/sir/2014/5133/.

Wilson, F.H., Hults, C.P., Schmoll, H.R., Haeussler, P.J., Schmidt, J.M., Yehle, L.A., and Labay, K.A., 2012, Geologic map of the Cook Inlet region, Alaska, including parts of the Talkeetna, Talkeetna Mountains, Tyonek, Anchorage, Lake Clark, Kenai, Seward, Iliamna, Seldovia, Mount Katmai, and Afognak 1:250,000-scale quadrangles: U.S. Geological Survey Scientific Investigations Map 3153, pamphlet 76 p., 2 sheets, scale 1:250,000, https://pubs.usgs. gov/sim/3153/. 
Moffett Field Publishing Service Center Manuscript approved June 30, 2021

Edited by Tim Herold

Illustration support by Kimber Petersen Layout by Cory Hurd 


\section{$\frac{2}{2}$}

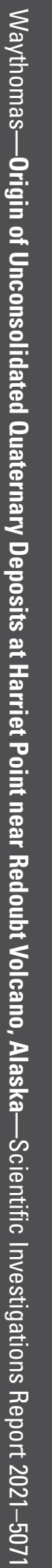

